\title{
A Study on the New Tendency of English Teaching Development in China
}

\author{
Gong Liping \\ College of Foreign Languages, Jiangxi Science and Technology Normal \\ University, Nanchang, Jiangxi, 330059, China
}

\begin{abstract}
With the development of the times, the application of English is more and more extensive, and English is the most widely used language in the world. In fact, since China's reform and opening up, many foreign companies have poured into the domestic market, which created a good opportunity to English using. Nowadays, a lot of english teaching workers have put into the research of english teaching. This paper will focus on the English teaching in the future development of a variety of trends as targeted research, only providing the reference for relevant practitioners.

Keywords: English teaching; reform; development; research trend

With the maturing of economic globalization, the rapid development of the knowledge and information age has forced the country to develop higher quality talents. They not only have to master the professional knowledge, but also have a high personal accomplishment and fluent communication skills in English. It has proved that China's traditional English teaching model is no longer meet the needs of social development, so it is necessary to address this issue to take appropriate measures to resolve. This paper starts from the learners' subject of English teaching, and their abilities of English application, cross-cultural communication and so on, and finally hopes to solve the existing drawbacks of English teaching in China.
\end{abstract}

\section{Pay attention to the study of English subjects}

In our country, English teaching is mainly how to teach, so many scholars look at the long-term English teaching materials on the preparation and design, ignoring 
the importance of how to learn. Today, English in China is already a popular language, and it can not only enhance the learning ability of students, but also make them to live in the social work for students. Therefore, in order to learn English well, one should devote oneself to the study of the subject study, so as to fundamentally solve the problem.

A Study is about individual factors affecting English learning. Personal factors in English learning is important, because everyone has differences, including cognitive and emotional. First of all, cognitive factors cover the scope more profoundly, they are mainly age, intelligence, cognitive level, and so on. Secondly, the emotional factors are mainly the attitude and motivation. China's English teaching and research workers have made a strong contributions to the development and setting of English education policy and curriculum, to a certain extent, to solve the age factor in English learning. Learning English naturally have relation of strong interests, so our experts and scholars are trying to explore how emotional factors can be positive for the learner to learn English.

\section{The study of eclectic teaching method in English teaching}

There are many types of English teaching methods, including audio-visual, cognitive, communicative and situational methods, which are closely related to English teaching methods, but also have their own distinctive personalities. For example, the translation method emphasizes grammar rules and the comparison of two languages, while ignoring the oral teaching. But direct method focuses on practical exercises to develop language habits, ignoring translation. Therefore, each teaching method has its own advantages, but the disadvantage can not be ignored.

At present, the eclectic theory and the individualized practice as the main theoretical study of methods in English teaching is no longer appearing unconventional teaching methods, while it is a trend of a variety of teaching methods and mutual integration. At the same time, in the practice of English teaching, the impact of the teaching environment is more emphasized to adopt an inclusive compromise approach and to better develop English teaching method.

\section{Emphasis on cultivation of learners' comprehensive application ability}

In recent years, our country has made scientific reform on the curriculum, teaching content and teaching system of English teaching, and devotes itself to how to bring into full play the role of students. It aims at cultivating students' comprehensive application ability and providing practical help for English teaching. The student-centered subject teaching model embodies three important teaching principles: "The first is to focus on students, focusing on the comprehensive application of students' language ability; followed by classroom 
teaching and extracurricular exercises organic combination, focusing on training students' self-study ability; the last is the design of classroom teaching to meet the requirements of students, focusing on mobilizing students' enthusiasm and participation in learning. "Because of the different stages of teaching training objectives, we must proceed from practice, not blind start. The main idea of this teaching model is to establish a student-centered teaching philosophy, teaching focus shifted to the cultivation of students on the language of integrated application ability.

\section{The focus of language testing theory from the evaluation of language factors to the actual use of language ability evaluation, and application evaluation of multimedia computer-assisted foreign language teaching mode}

English teaching is facing a huge challenge, it's clear in the performance of the language test. At first people's understanding of the language is not deep enough, leading to the development of English teaching lag. However, with the rapid development of the information age, resulting in more and more profound understanding of the language, showing science and reason. In the early days, language was perceived as a knowledge which was the goal of learning, and was not recognized how it can be communicative application. In the language test, the authors only set up several more traditional test model, such as "ChineseEnglish" and "Cloze" and so on. To the communicative language testing period, English teaching workers have found this malpractice, so set a relatively new type of questions, designed to improve student interest in learning, focusing on cultivating English communicative competence.

Nowadays, many colleges and universities in China have set up language application ability test links in English class, which mainly shows as "test, listen, read, write and translate", it is impossible to master one of them. To learn English well, we must master the five basic skills of English, only to be comprehensive, can we make English in communication to reflect our values.

Seizing the opportunity of the information age, playing the value of multimedia computers, and applying in English teaching scientifically and rationally, can get good results. Computer debug language test is a new method in information technology, and has become a new approach to the development of English teaching. In China, the English Examinations Committee is strongly committed to the reform of English teaching mode, closely around the application of multimedia computers, has made achievement. Therefore, the effectiveness of multimedia computers can not be underestimated, we must study how it can improve the quality of English teaching, how to enable students to participate in English learning, and it in the future for a long time, will become the best adjunct for English teaching. 


\section{To enhance the overall quality of research methods, teaching content from pure language teaching to cross-cultural communication.}

It's obvious that our level of English teaching still has the gap with the international community, and even some engaged in English teaching workers are still using more traditional teaching model. English as an international universal language, naturally has its deep meaning. In social communication, the use of English has an unshakable position, even if our Chinese as a national language, not ignoring its role. Therefore, if the English teaching method is not a fundamental innovation, it will seriously affect the integration of China to the world.

At present, many English teaching scholars have put into how to teach English to use the ability to work. If you want to learn English well, the first thing to do is to understand English, only in this way, can English in crosscultural communication reflect the value of learning. Today, many colleges and universities have begun to pay attention to this serious problem, and have taken measures to deal with. For example, their English teachers in the English classroom increase the cultural introduction as premise, focusing on students' ability to communicate in English, so students learn English process, not only learned about different cultures, but pay more attention to speech norms. In fact, the contents of English teaching research is no longer vague, but specific, and the researchers found a number of key points, and broke one by one. There are many methods of English teaching, including comparative method, which is a method of comparing English and Chinese culture, which can make the students understand the importance of learning English well. Students in the process of learning English, not just rely on the theory of filling their brains, but should be "ready to learn", to enhance their English communication skills in social practice.

\section{English teaching and learning all-round research under multi-media network technology environment}

China's English teaching model still stressed the importance of teachers, and did not recognize the role of students as the main body. Therefore, this trend has led to serious lag in the cause of English teaching in China, in order to conform with international standards, it is necessary to enhance the students to learn English and use English. In today's world, the Internet has played a huge role in stepping up contact with countries around the world. Therefore, we must seize this opportunity to make full use of multimedia Internet capabilities for English teaching work to provide a powerful help. At present, many colleges and universities in China have introduced multimedia Internet technology into English teaching work, so that teaching space and content is no longer binding, and in the wider world of the Internet, which gives students full English learning 
platform. It can not only improve the students' interest in learning English, but also enhance the students' ability of autonomous learning and improve the efficiency of English learning. Network teaching model is not new, in many countries, universities, the application of this teaching model is extremely common, making the English teaching achieve very good development.

In fact, no matter how much the introduction of China's English teaching methods, it can not get the appropriate return. Because the theory of English teaching in China has been focused on teaching methods, and did not attach importance to the needs of learners themselves. However, through the abovementioned six major trends, we understand that our country is gradually out of the traditional mode of English teaching, more to close to the autonomy and rationality. This is also social needs of talents in the new era, we have to train allround talents. Learning English well can get high marks, but using English well can be based on the community, and ultimately serve the community.

\section{Conclusion}

For now, China has introduced a number of favorable English teaching policies, but also achieved good results. However, if we want to do a good long-term work, we must be down to earth to fundamentally solve the problem of English teaching. We will study the factors that impede the development of English teaching and make a reasonable analysis of these factors. We should adhere to the principle of "exploring the root" and earnestly do a good job in English teaching. In addition, teachers and students need to understand their own posture to fulfill the implementation of "how to teach, how to learn" work, the "individualized" method of scientific application to students. Even now it seems a long way to go, but as long as each english teaching workers attach importance to this thing, English teaching work will be developed.

\section{References:}

[1] Wang Chuming. Two Factors Affecting Foreign Language Learning and Foreign Language Teaching [J]. Foreign Language, 2001, (6).

[2] Wen Qiufang, Wang Lifei. 20 Years of Empirical Study on English Learning Strategies in China [J]. Foreign Language and Literature, 2004, (1).

[3] Li Yincang. On the Emotional Goals of Foreign Language Teaching [J]. Foreign Language Teaching, 2005, (3).

[4] Liu Runqing. On College English Teaching [M]. Beijing: Foreign Language Teaching and Research Press, 1995. 